\title{
Analisis Potensi Kebohongan dengan Galvanic Skin Response Dan Diameter Pupil Mata
}

\author{
Adhadi Kurniawan ${ }^{1 *}$, Junas Haidi ${ }^{2 *}$, M. Khairul Amri Rosa ${ }^{3 *}$, Jefri Suryanata ${ }^{4 *}$ \\ 1,2,3, Program Studi Teknik Elektro Universitas Bengkulu
}

\begin{abstract}
ABSTRAK
Sistem alat pendeteksi kebohongan pada penelitian ini menggunakan sistem kerja dari GSR (Galvanic Skin Response) dan perubahan diameter pupil mata seseorang untuk melihat perubahan resistansi ataupun perubahan respon kulit yang terdapat pada jari tengah dan telunjuk seseorang menggunakan sensor GSR dan menggunakan kamera webcam Logitech B525 HD untuk melihat perubahan diameter pupil mata pada seseorang. Analisa pada penelitian ini untuk melihat perubahan resistansi kulit atau $\mathrm{Rk}$ dan perubahan ukuran diameter pupil mata atau $\mathrm{X}$ yang berpotensi berbohong atau tidak. Pengujian dilakukan sebanyak empat kali untuk membuktikan perubahan resistansi kulit atau Rk dan ukuran diameter pupil mata atau X. Pada pengujian perubahan nilai resistansi kulit atau Rk pada pengujian kedua perubahan resistansi kulit atau $\mathrm{Rk}$ terjadi didetik 12 sebesar 0,244 dan pengujian ketiga didetik 12 dan 16 sebesar 1,018. Sedangkan pengujian perubahan ukuran diameter pupil mata $X$ perubahan terjadi pada pengujian pertama didetik ke 11 sebesar 1 , $31 \mathrm{~mm}$ dan detik 19 sebesar $0,92 \mathrm{~mm}$ dan pengujian kedua didetik ke 12 sebesar $1,1 \mathrm{~mm}$.
\end{abstract}

Kata kunci: Galvanic Skin Response, Pupil Mata, Bohong

\section{Pendahuluan}

Setiap orang memiliki kepribadiannya masingmasing, ada yang suka dengan jujur ada juga yang sering berbohong. Seringkali dengan niat untuk menjaga rahasia atau menjaga sesuatu dalam hal menghindari hukuman seseorang harus melakukan kebohongan. Kebohongan adalah jenis penipuan dalam bentuk pernyataan yang tidak benar terutama dengan maksud untuk menipu orang lain.

Pada situs detikhealth mengutip dari NBC News bahwa di Amerika Serikat menemukan rata-rata orang melakukan kebohongan sekitar 11 kali dalam rentang waktu seminggu dalam sebuah studinya sedangkan pada riset yang lain memperlihatkan bahwa $60 \%$ orang melakukan kebohongan dalam satu kali 10 menit. Riset ini telah dipublikasikan oleh Journal of Basic and Applied Social Psychology. Menurut seorang konselor di Wake Forest University, Amerika Serikat, Leslie Martin, $\mathrm{PhD} 37 \%$ latar belakang seseorang melakukan kebohongan adalah untuk melindungi dirinya sendiri dari rasa malu dan mempertahankan harga diri.
Salah satu bidang dalam hal kebohongan, salah satunya adalah proses rekrutment karyawan. Sering kali beberapa perusahan menggunakan instrument untuk mendapatkan karyawan yang sesuai dengan yang dicari perusahaan. Instrument tersebut terkadang hanya mengandalkan beberapa soal tes psikologi ataupun wawancara sehingga terkadang belum sesuai dengan harapan.

Potensi keinginan seseorang mau berbohong biasanya terkait psikologi seseorang. Psikologi seseorang ini dapat diamati dengan beberapa perubahan respon fisikologis tubuh seperti dengan bertambahnya jumlah detak jantung, pernapasan, perubahan produksi keringat, panas tubuh, getaran suara, pembesaran pupil mata, gugup yang berlebih, respon elektromagnetik pada syaraf telapak dan jari tangan dan lainnya [1].

Penelitian [2] mengecek kejiwaan seseorang, dengan parameter kesehatan fisik dan jiwa. Pada penelitian ini membuat alat yang mampu membaca detak jantung, suhu tubuh, saturasi oksigen dan GSR. Hasilnya pada penelitian in adalah mampu mengukur status kesehatan tanda vital dan tingkat stress. Sedangkan penelitian [3] merancang alat untuk mengidentifikasi kebohongan dengan sensor GSR. Hasilnya adalah alat tersebut mempunyai akurasi kebenaran $57 \%$.

Pada penelitian ini menganalisis potensi kebohongan berdasarkan konduktivitas kulit. Perubahan-perubahan respon fisikologis ini dapat dianalisis dengan menggunakan respon elektromagnetik pada kulit seseorang. Respon elektromagnetik ini sering disebut Galvanic Skin Response (GSR).

Selain menggunakan GSR (Galvanic Skin Response) ada beberapa penelitian terkait pada kebohongan pernah dilakukan oleh Abdul Jabar Lubis. Penelitian ini menggunakan perubahan diameter pupil mata dengan teknik Thresholding. Pada penelitian ini pupil mata akan dipisahkan dari bagian mata yang lain dan dihitung luas kemudian dihitung diameter pupil [4] Pada perancangan alat ini proses yang dilakukan meliputi penerangan mata oleh sumber cahaya infra merah agar pupil mata dapat dapat ditangkap oleh kamera secara online. Dari kamera disambungkan ke PC menggunakan bantuan Bahasa VB untuk proses selanjutnya. Melalui proses threholding, pupil mata akan dipisahkan dari bagian mata yang lain dan dihitung luas 
kemudian diameter pupil. Dari hasil perhitungan diameter pupil mata, dibuat grafik perubahan diameter pupil mata terhadap waktu. Hasil uji coba menunjukkan keberhasilan dalam mendeteksi orang berbohong sebesar $74.44 \%$, orang berbohong tereteksi jujur sebesar $25.55 \%$, orang jujur yang terdeteksi berbohong sebesar $57.27 \%$, dan orang jujur terdeteksi jujur sebesar $42.72 \%$. kekurangan penelitian ini persentase orang jujur yang terdeteksi berbohong hampir sama dengan orang jujur terdeteksi jujur dan kedipan mata sangat berpengaruh terhadap kinerja alat pada penelitian ini. Dari beberapa kasus tersebut maka peneliti mencoba menganalisis potensi kebohongan dengan menggunakan Galvanic Skin Response (GSR) dan Diameter Pupil Mata. Analisis tentang kebohongan ini termasuk hal yang sangat penting

\section{TINJAUAN PUSTAKA}

\section{A. Galvanic Skin Response (GSR)}

Galvanic Skin Response (GSR) adalah perubahan yang terjadi pada kulit. GSR ini sangat sensitive terhadap perubahan atau kondutifitas resistansi kulit. Perubahan ini akibat dari aktivitas-aktivitas kelenjar keringat yang membuat kondisi tubuh dalam keadaan stress atau tertekan sehingga kelenjar keringat aktif.

Pada kulit manusia mempunyai sifat kelistrikan. Kulit manusia dapat bisa dianggap menghantarkan arus listrik dengan menggunakan resistansi tertentu. Resistansi tersebut dapat berubah tergantung dengan jumlah banyak ataupun sedikit keringat yang aktif. Sebagai contoh orang yang berbohong cenderung berkeringat dibandingkan orang yang jujur karena keringat merupakan larutan yang mampu menghantarkan listrik (larutan elektrolit) sehingga kebohongan ditentukan dengan melihat perubahan daya hantar listrik pada kulit. Pada bagian kulit tertentu yang dianggap memiliki kelenjar keringat yang paling sensitive atau jumlah konsentrasi paling tinggi dipasang konektor yang langsung terhubung dengan telapak tangan. Tujuannya adalah mendapat respon yang maksimal.

Penggunaan sensor GSR tidak sembarangan sesuai dengan namanya galvanic skin resistance (response) sensor ini hanya akan bekerja ketika diletakkan atau digunakan pada kulit tertentu, karena ditubuh manusia memiliki resistansi dan kepekaan yang berbeda-beda dalam mengisyaratkan perubahan pada tubuh, kebanyakan syaraf manusia terhubung pada telapak tangan dan kaki karena pada daerah ini memiliki syaraf yang terhubung keseluruh tubuh.

Dalam kasus pendeteksian tekanan, stres, dan kebohongan seseorang biasanya diletakkan pada jari telunjuk dan tengah seseorang karena pada bagian ini mendeteksi tingkat stes ataupun tekanan pada seseorang. Kebanyakan sensor GSR digunakan untuk melihat

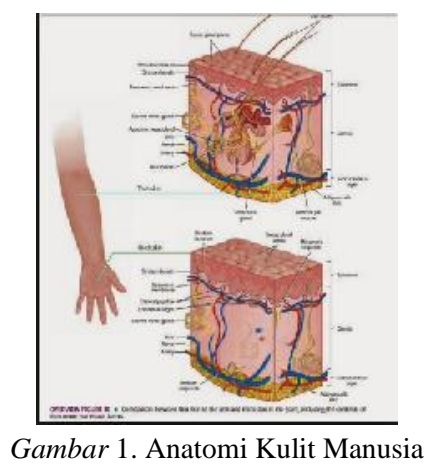

tingkat stres seseorang akan tetapi dalam perkembangan teknologi, sensor ini digunakan juga untuk mendeteksi kebohongan, karena tingkat stres seseorang itu berbanding lurus dengan tingkat kejujuran seseorang [5].

\section{B. Kulit Manusia}

Kulit merupakan salah satu panca indra yang berfungsi sebagai sensor tubuh. Misalkan untuk merasakan tekstur benda, perubahan suhu dan lain-lain. Kepekaan kulit pada tubuh manusia berbeda-beda tergantung dengan tebal kulit itu sendiri. Kepekaan kulit paling tinggi terletak pada bagian telapak tangan dan kaki.

Kulit adalah suatu pembungkus yang elastik yang melindungi tubuh dari pengaruh lingkungan, kulit juga merupakan alat tubuh terberat dan terluas ukurannya yaitu $15 \%$ dari berat tubuh manusia, rata rata tebal kulit 1-2 mm, kulit terbagi atas 3 lapisan pokok yaitu, epidermis, dermis dan subkutan atau subkutis.

Subkutis terdiri dari kumpulan sel lemak dan di antara gerombolan ini berjalan serabut jaringan ikat dermis. Sel-sel lemak ini bentuknya bulat dengan inti yang terdesak kepinggir, sehingga membentuk seperti cincin. Lapisan lemak disebut penikulus adiposus yang tebalnya tidak sama pada setiap tempat. Fungsi penikulus adiposus adalah sebagai shock braker atau pegas bila terdapat tekanan trauma mekanis pada kulit, isolator panas atau untuk mempertahankan suhu, penimbunan kalori, dan tambahan untuk kecantikan tubuh. Dibawah subkutis terdapat selaput otot kemudian baru terdapat otot. Vaskularisasi kulit diatur oleh dua pleksus, yaitu pleksus yang terletak dibagian atas dermis (pleksus superficial) dan yang terletak di subkutis (pleksus profunda). Pleksus yang terdapat pada dermis bagian atas mengadakan anastomosis di papil dermis, sedangkan pleksus yang di subkutis dan di pars retikular juga mengadakan anastomosis, dibagian ini pembuluh darah berukuran lebih besar. Bergandengan dengan pembuluh darah terdapat saluran getah bening.

\section{Mata}

Mata merupakan alat indra yang terdapat pada manusia yang secara konstan menyesuaikan pada jumlah 


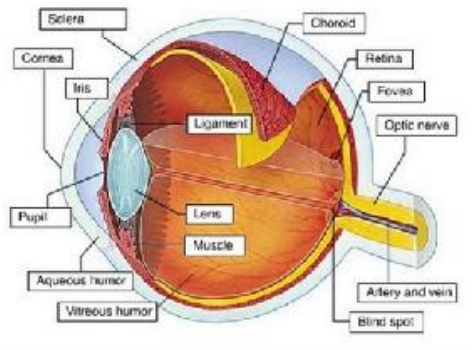

Gambar 2. Anatomi Mata

cahaya yang masuk, memusatkan perhatian pada objek yang dekat dan jauh serta menghasilkan gambaran yang kontinyu yang dengan segera di hantarkan pada otak. Penglihatan pada manusia melibatkan deteksi gelombang cahaya yang sangat sempit dengan panjang gelombang sekitar 400 sampai $750 \mathrm{~nm}$. Panjang gelombang terpendek dipersepsi sebagai warna biru, dan panjang gelombang terpanjang dipersepsi sebagai warna merah. Mata memiliki fotoreseptor yang mampu mendeteksi cahaya, tetapi, sebelum cahaya mengenai reseptor yang bertanggung jawab untuk deteksi ini, cahaya harus difokuskan ke retina ( ketebalan 200 m) oleh kornea dan lensa.

Iris adalah diafragma yang melingkar dan berpigmen dengan lubang agak di tengah, yaitu pupil. Pupil menentukan kuantitas cahaya yang masuk ke bagian mata yang lebih dalam. Pupil mata akan melebar jika kondisi ruangan yang gelap, dan akan menyempit jika kondisi ruangan terang. Sebagian iris terletak di bagian depan lensa dan sebagian lainnya berada di depan badan siliaris. Iris terdiri atas serat otot polos. Fungsi iris untuk mengendalikan jumlah cahaya yang masuk ke mata. Kornea adalah kubah transparan yang agak pipih yang membentuk seperenam bagian anterior dinding. Kornea memiliki inervasi saraf tetapi avaskuler (tidak memiliki suplai darah).

\section{Prinsip Kerja Perubahan Diameter Pupil Mata}

Dalam mengetahui perubahan diameter pupil mata, pertama-tama yang dilakukan adalah proses thresholding. Proses ini memisahkan pupil mata dengan bagian mata yang lain. Hal ini dapat dilakukan dengan menentukan nilai thresholding yang tepat. Langkah selanjutnya lakukan proses penghitungan piksel hitam untuk mengetahui luas pupil mata saat diketahui luas pupil mata, maka dilakukan proses pengukuran diameter pupil mata saat diameter pupil mata diketahui, maka dibuat grafik perubahan diameter pupil mata terhadap waktu. Pengujian dilakukan dengan menempatkan mata didepan kamera, sehingga pupil mata terlihat dan dapat dideteksi perubahan diameternya.

Setelah pupil mata dapat dideteksi dilakukan proses

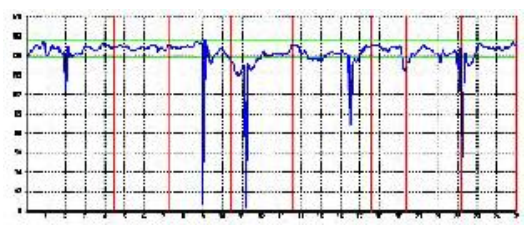

Gambar 3.Grafik Perubahan Diameter Pupil Mata

thresholding untuk memisahkan pupil mata dengan bagian mata lainnya. Proses ini dilakukan evaluasi dengan melihat apakah bagian pupil mata dapat dipisahkan dengan bagian mata yang lain atau tidak, jika tidak maka dilakukan pengubahan thresholding untuk mendapatkan bagian pupil mata yang terpisah dengan bagian yang lain. Setelah diketahui diameter pupil mata, dibuat grafik perubahan diameter pupil mata terhadap waktu. Gambar berikut merupakan Grafik perubahan diameter pupil mata terhadap waktu. Untuk menentukan apakah seseorang berbohong atau tidak terdapat batas bawah dan batas atas yang menjadi acuan dengan nilai $10 \%$ untuk batas bawah dan $10 \%$ untuk batas atas dari ukuran awal pupil.

Ini dilakukan untuk mengetahui tingkat keberhasilan yang telah direncanakan sekaligus mengetahui tingkat keberhasilan yang telah direncanakan sekaligus mengetahui adanya kelemahan atau kekurangan sehingga dapat dilakukan beberapa perbaikan bila diperlukan.

\section{Metode Penelitian}

Perancangan alat pendeteksi kebohongan ini akan menggunakan dua tahapan perancangan untuk sistem utama yaitu perancangan perangkat keras dan perancangan perangkat lunak serta menganalisa hasil pembacaan data.

\section{E. Perancangan Perangkat Keras}

Perancangan perangkat keras yaitu mengetahui komponen yang digunakan serta algoritna kerja. Selanjutnya merancang komponen-komponen yang digunakan seperti sensor-sensor, Arduino, dan perangkat pendukung lainya.

\section{F. Perancangan Perangkat Lunak}

Perancangan perangkat lunak adalah perancangan mengelola program agar mikrokontroller dapat memberi instruksi pada perangkat keras. Membaca semua refrensi yang berkaitan dilakukan untuk mempelajari seluruh aspek toeritis dari referensi yang digunakan agar nantinya diperoleh suatu sistem pembacaan yang baik dalam membaca kondisi tubuh berdasarkan parameter sensor yang digunakan. 


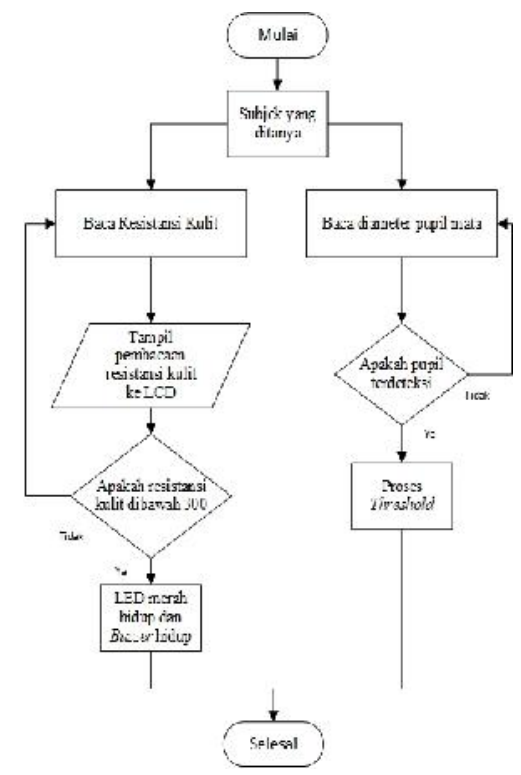

Gambar 4. Diagram Alir Sistem Keseluruhan

\section{G. Cara Kerja Sistem Pendeteksi Kebohongan GSR dan Diamter Pupil Mata}

Sistem ini memiliki cara kerja yaitu memanfaatkan sensor GSR (Galvanic Skin Response) dan perubahan pada diameter pupil mata untuk mengindrakan kerja tubuh dan mengirimkan data dari sensor yang terpasang pada bagian tubuh. Sistem dirancang untuk mendeteksi kulit dan diameter pupil mata manusia. Kinerja tubuh manusia akan dipantau berupa kelenjar keringat yang dikeluarkan pada jari, nilai resistansi kulit secara realtime dan perubahan diameter pupil mata. Pengindikasian ini didapat dari hasil pengindraan melalui sensor GSR dan webcam Logitech B525. Setelah data mengenai pengukuran dari tubuh didapat maka data akan diolah oleh pusat kontrol untuk mengetahui kondisi seseorang dengan membandingkan nilai pengukurannya dengan nilai setpoint setiap sensor. Pada saat pemantauan juga diberikan batasan nilai rate pada setiap sensor yaitu nilai minimum dan maksimum jika nilai kurang atau melebihi nilai rata-rata pada sensor maka alat ini akan memberi peringatan potensi tanda-tanda seseorang mulai berbohong. Adapun diagram alir dapat dilihat pada Gambar 4.

\section{G. Metode Pengujian}

Pengujian pada sistem ini untuk melihat kinerja pada alat yang bekerja dengan baik dan sesuai dengan keinginan dalam potensi kebohongan dengan GSR dan diameter pupil mata.

\section{H. Pengujian Galvanic Skin Resistance (GSR)}

Pengujian galvanic skin resistance ini melihat perubahan tahanan atau resistansi kulit pada seseorang menggunakan prinsip kerja galvanic skin response. Perubahan yang terjadi dilihat pada LCD yang terhubung pada arduino nano. Dari nilai sensor yang didapat maka dapat dihitung nilai tegangan yang dihasilkan sensor dengan menggunakan persamaan 3.1 dan resistansi kulit menggunakan persamaan 3.2. setelah itu untuk melihat perubahan resistansi kulit dari setaip pertanyaan digunakan persamaan 3.3.

Vsensor $=$ Sensor Value $\left(\frac{\text { Vin }}{1023}\right)$

Ket: Sensor Value = Nilai Terbaca Sensor (ADC) Vin $\quad=$ Tegangan Input (Volt)

$R k=\frac{V_{\text {sensor }}^{2}}{p}$

Ket: Rk = Resistansi Kulit $(\Omega)$

Vsensor = Tegangan sensor GSR (Volt)

$\mathrm{P} \quad$ = Daya $($ Watt $)$

$\Delta R k=|\pi k n \quad R k a|$

Ket: $\mathrm{Rkn}=$ resistansi kulit setelah diberi pertanyaan

$\mathrm{Rka}=$ resistansi kulit sebelum diberi pertanyaan

\section{Pengujian Diameter Pupil Mata}

Pengujian pendeteksian diameter pupil mata menggunakan kamera webcam Logitech B525.Tujuan pengujian ini untuk melihat perubahan diameter pupil mata ketika diberi pertanyaan setiap subjek memiliki ukuran pupil yang berbeda-beda untuk mengetahui seseorang berbohong atau tidak ukuran pupil mata awal tidak boleh melewati nilai batas bawah dan nilai batas atas. Perubahan yang terjadi kemudian diamati menggunakan MATLAB. Untuk melihat perubahan dan ukuran diameter pupil mata pada setiap pertanyaan menggunakan persamaan 3.4. untuk melihat perubahan ukuran pupil mata menggunakan persamaan 3.5

$$
X=M v\left(\frac{P \text { pupil }}{P \text { mata }}\right)
$$

Ket: $\quad \mathrm{X}=$ Diameter pupil $(\mathrm{mm})$

$\mathrm{Mv}=$ ukuran mata di video $(\mathrm{mm})$

P pupil = Pixel pupil.

$\mathrm{P}$ mata $=$ Pixel mata.

$$
\Delta X=\mid X n-X a
$$

Ket: $\mathrm{Xn}=$ Diameter pupil setelah diberi pertanyaan $\mathrm{Xa}=$ Diameter Pupil awal 


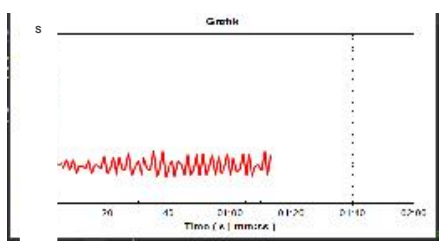

Gambar 5. Gratık Perubahan GSR Cenderung Jujur

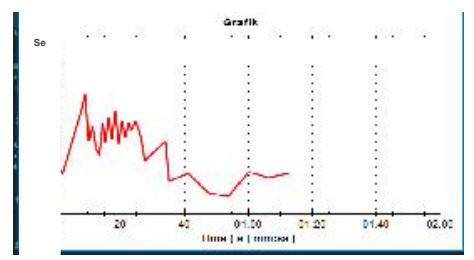

Gambar 6. Grafik Perubahan GSR Cenderung Bohong

\section{J. Analisis dan Pembahasan}

Pengujian dilakukan untuk mengetahui kesesuaian antara hasil dari penelitian dengan perancangan yang telah dibuat dan mengetahui tingkat keberhasilan dari alat tersebut. Berdasarkan hasil pengujian maka dapat dianalisa kinerja dari tiap-tiap bagian yang saling berinteraksi. Pengujian selanjutnya dilakukan dengan menganalisis perubahan tahanan yang terjadi di kulit (Galvanic Skin Response) dan mengamati perubahan diameter pupil mata. Setelah GSR (Galvanic Skin Response) dan program yang mengamati perubahan diameter pupil mata berjalan maka dilakukan analisa pengamatan apakah subjek mempunyai potensi berbohong atau tidak.

\section{K. Pengujian Alat Pendeteksi Kebohongan \\ K.1. Pengujian Galvanic Skin Resistanse}

Pada pengujian Galvanic Skin Resistanse ini melihat perubahan tahanan kulit setiap subjek menggunakan prinsip kerja Galvanic Skin Response (GSR). Jumlah pertanyaan yang diajukan pada setiap subjek berjumlah 5 pertanyaan. Perubahan yang terjadi dilihat pada LCD yang terhubung pada Arduino Nano dengan menggunakan IDE. Untuk mempermudah dalam pengambilan data dan analisis maka perubahan tahanan kulit subjek dibuat dalam bentuk gelombang yang terhubung dengan Visual Basic. Contoh bentuk gelombang dapat dilihat pada Gambar 5 dan 6 .

\section{K.2. Pengujian Diameter Pupil Mata}

Pada pengujian diameter pupil mata bertujuan untuk melihat perubahan diameter pupil mata pada setiap subjek ketika ditanya, pertanyaan yang diajukan pada setiap subjek berjumlah 5 pertanyaan. Perubahan yang

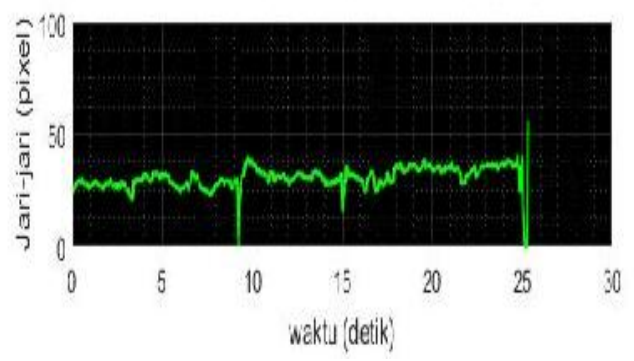

Gambar 7. Grafik Perubahan Diameter Pupil Mata Cenderung Jujur

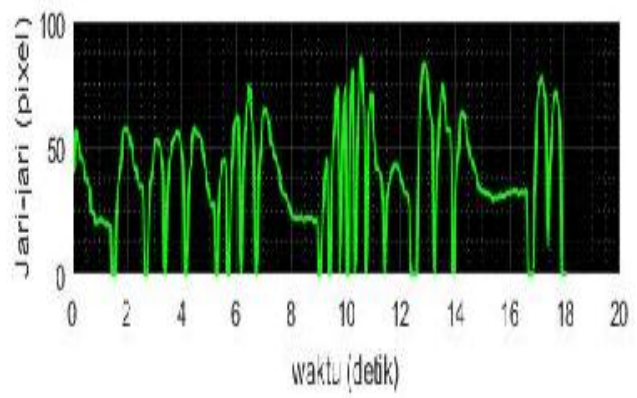

Gambar 8. Grafik Perubahan Diameter Pupil Mata Cenderung Bohong

terjadi kemudian diamati menggunakan kamera yang terhubung dengan aplikasi MATLAB. Perubahan yang terjadi dapat dilihat pada Gambar 7 dan Gambar 8. Pada Gambar 7 terlihat gelombang yang ada tidak menunjukkan perubahan yang signifikan, itu menandakan bahwa subjek mempunyai potensi berkata jujur. Sedangkan pada Gambar 8 terlihat perubahan gelombang yang signifikan, yang ditunjukkan pada Gambar 8 menandakan bahwa subjek mempunyai potensi berkata tidak jujur.

\section{K.3. Perhitungan Resistansi Kulit dan Diameter Pupil Mata}

Pada subjek yang ingin diteliti apakah mempunyai potensi berkata jujur atau berbohing maka dilakukan perhitungan resistansi kulit dan diameter pupil mata pada 4 subjek berikut yang dapat mewakili tiga puluh subjek yang ada menggunakan persamaan 3.1, 3.2 dan 3.3. Nilai perubahan tegangan sensor GSR, resistansi kulit dan diameter pupil mata setiap subjek.

\section{Analisa Alat Pengujian Pertama}

Pengujian pertama setelah dilakukan perhitungan dapat dilihat dari nilai rata-rata tegangan sensor GSR sebesar 1,773 Volt yang dihasilkan nilai rata-rata resistansi kulit subjek pertama sebesar 5,234 dapat dilihat pada Tabel 1 Hasil pengujian GSR pertama. 
TABEL 1

Hasil Pengujian GSR dan Diamter Pupil Mata Pengujian PERTAMA

\begin{tabular}{cccc}
\hline Waktu (s) & $\begin{array}{c}\text { Tegangan } \\
\text { Sensor GSR } \\
(\mathbf{V})\end{array}$ & $\begin{array}{c}\text { Resistansi } \\
\text { Kulit } \\
(\boldsymbol{\Omega})\end{array}$ & Rk ( ) \\
\hline 0 & 1,78 & 5,28 & 0 \\
3 & 1,769 & 5,21 & $-0,07$ \\
7 & 1,764 & 5,18 & $-0,1$ \\
11 & 1,774 & 5,24 & $-0,04$ \\
14 & 1,779 & 5,27 & $-0,01$ \\
19 & 1,779 & 5,27 & $-0,01$ \\
Jumlah & 10,61 & 31,45 & $-0,23$ \\
Rata-rata & 1,769 & 5,24 & $-0,038$ \\
\hline
\end{tabular}

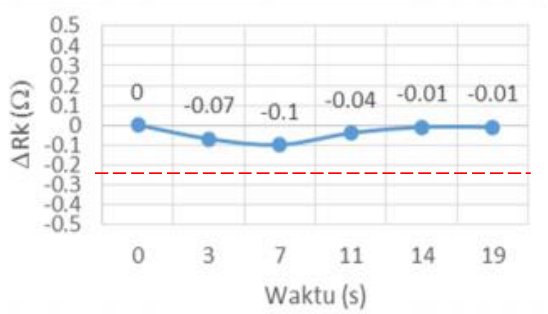

Gambar 9. Grafik Perbandingan Waktu Terhadap Rk Pengujian Pertama

Tabel 2 Hasil Pengujian Diameter Pupil Mata Pengujian Pertama

\begin{tabular}{ccc}
\hline Waktu (s) & $\begin{array}{c}\text { Diameter Pupil } \\
\text { Mata (mm) }\end{array}$ & X (mm) \\
\hline 0 & 3,92 & 0 \\
3 & 3,66 & $-0,26$ \\
7 & 3,92 & 0 \\
11 & 5,23 & 1,31 \\
14 & 4,18 & 0,26 \\
19 & 4,84 & 0,92 \\
Jumlah & 25,75 & 2,23 \\
Rata-rata & 4,29 & 0,37 \\
\hline
\end{tabular}

Dari Tabel 1 hasil pengujian GSR pertama dapat dilihat nilai rata-rata resistansi kulit sebesar 5,24 dengan nilai rata-rata perubahan resistansi kulit atau Rk sebesar 0,038 ini menandakan bahwa subjek pertama cenderung tenang dan tidak gugup dalam pengujian pendeteksi kebohongan. Setelah itu dapat dibuat Grafik perbandingan tahanan terhadap perubahan tegangan sensor GSR yang dihasilkan pada Gambar 9.

Dari Gambar 9 dapat dilihat grafik perbandingan waktu terhadap perubahan resistansi kulit atau $\mathrm{Rk}$ pengujian pertama nilai resistansi kulit tidak

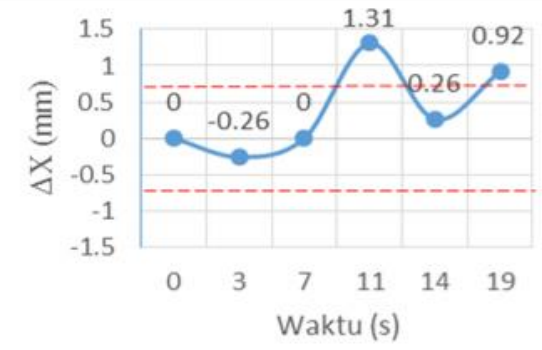

Gambar 10. Grafik Perbandingan Waktu Terhadap X Pengujian Pertama

Tabel 3. Hasil Pengujian GSR Pengujian Kedua

\begin{tabular}{cccc}
\hline $\begin{array}{c}\text { Waktu } \\
(\mathrm{s})\end{array}$ & $\begin{array}{c}\text { Tegangan } \\
\text { Sensor } \\
\text { GSR (V) }\end{array}$ & $\begin{array}{c}\text { Resistansi } \\
\text { Kulit ( ) }\end{array}$ & Rk ( ) \\
\hline 0 & 0,78 & 1,014 & 0 \\
4 & 0,78 & 1,014 & 0 \\
8 & 0,75 & 0,937 & $-0,077$ \\
12 & 0,68 & 0,77 & $-0,244$ \\
18 & 0,78 & 1,014 & 0 \\
24 & 0,73 & 0,88 & $-0,134$ \\
Jumlah & 4,5 & 5,629 & $-0,455$ \\
Rata-rata & 0,75 & 0,93 & $-0,075$ \\
\hline
\end{tabular}

menunjukkan perubahan yang signifikan ini menandakan bahwa pada pengujian pertama subjek dalam keadaan tenang dan cenderung memberikan pernyataan sesuai dengan pertanyaan yang diberikan atau cenderung jujur.

Dari Tabel 2 Setelah dilakukan perhitungan ukuran diameter pupil mata dapat dibuat grafik perbandingan waktu terhadap perubahan diameter pupil mata atau $\mathrm{X}$ pada Gambar 4.8.

Dari Gambar 10 terlihat perubahan nilai ukuran diameter pupil mata pada detik 11 dan 19 dari nilai X awal $0 \mathrm{~mm}$ tiba-tiba berubah menjadi $1,31 \mathrm{~mm}$ untuk detik 11 dan 0,92 mm untuk detik 19, ini menandakan bahwa pada detik ke 11 dan 19 untuk pengujian pertama berpotensi tidak jujur karena melewati batas yang telah ditentukan.

\section{Analisa Alat Pengujian Kedua}

Pengujian kedua ini setelah dilakukan perhitungan dapat dilihat rata-rata tegangan sensor GSR sebesar 0,75 $\mathrm{V}$ dan resistansi kulit sebesar 0,93 serta perubahan nilai resitansi atau Rk sebesar 0,075 . Hasil pengujian kedua ini dapat dilihat pada Tabel 3 dibawah ini.

Dari Tabel 3 dapat dibuat grafik perbandingan waktu terhadap nilai perubahan nilai resistansi kulit atau Rk untuk pengujian kedua dapat dilihat pada Gambar 11 dibawah ini. 


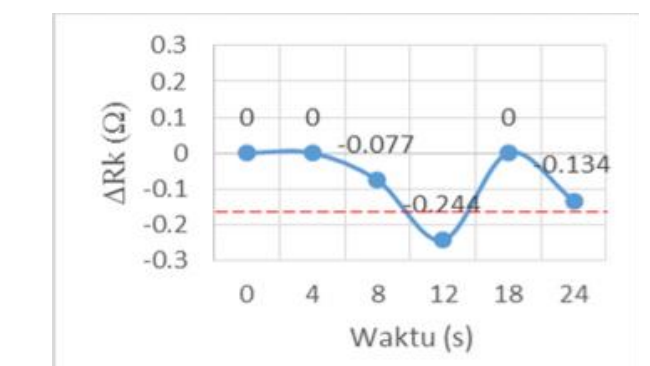

Gambar 11. Grafik Perbandingan Waktu Terhadap Rk Subjek Pengujian Kedua

Tabel 4. Diameter Pupil Mata Pengujian Kedua

\begin{tabular}{ccc}
\hline Waktu (s) & $\begin{array}{r}\text { Diameter } \\
\text { Pupil } \\
(\mathrm{mm})\end{array}$ & $\mathrm{X}(\mathrm{mm})$ \\
\hline 0 & 5,51 & 0 \\
4 & 5,29 & $-0,22$ \\
8 & 5,29 & $-0,22$ \\
12 & 6,61 & 1,1 \\
18 & 6,06 & 0,55 \\
24 & 6,06 & 0,55 \\
Jumlah & 34,82 & 1,76 \\
Rata-rata & 5,8 & 0,29 \\
\hline
\end{tabular}

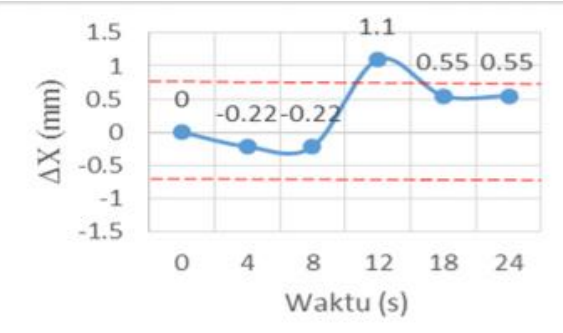

Gambar 12. Grafik Perbandingan Waktu Terhadap X Subjek Pengujian Kedua

Dari Gambar 11 dapat dilihat pada detik ke 12 perubahan nilai resistansi kulit atau Rk pengujian kedua melewati batas nilai yang telah ditentukan sebesar 0,244 . Dari perubahan nilai resitansi kulit tersebut maka pada pengujian kedua ini berpotensi berbohong.

Setelah melakukan pengujian GSR maka dilakukan perhitungan ukuran diameter pupil mata. Pada pengukuran diameter pupil mata pada pengujian kedua ini nilai rata-rata pada diameter pupil sebesar $5,8 \mathrm{~mm}$ dan perubahan nilai ukuran diameter pupil mata atau $\mathrm{X}$ sebesar $0,29 \mathrm{~mm}$. Tabel 4 menunjukkan pengujian kedua pengukuran diameter pupil mata.

Dari data Tabel 4 dapat dibuat grafik perbandingan waktu terhadap perubahan ukuran diameter pupil atau X pada Gambar 12.

Dari Gambar 12 terlihat perubahan pupil mata cukup bervariasi dan terlihat pada detik $12 \mathrm{~s}$ terlihat
Tabel 5. Hasil Pengujian GSR Pengujian Ketiga

\begin{tabular}{cccc}
\hline Waktu (s) & $\begin{array}{c}\text { Tegangan } \\
\text { Sensor GSR } \\
(\mathrm{V})\end{array}$ & $\begin{array}{c}\text { Resistansi } \\
\text { Kulit ( ) }\end{array}$ & Rk ( ) \\
\hline 0 & 1,07 & 1,908 & 0 \\
3 & 0,928 & 1,43 & $-0,478$ \\
7 & 0,879 & 1,28 & $-0,628$ \\
12 & 0,733 & 0,89 & $-1,018$ \\
16 & 0,733 & 0,89 & $-1,018$ \\
20 & 0,782 & 1,019 & $-0,889$ \\
Jumlah & 5,125 & 7,417 & $-4,031$ \\
Rata-rata & 0,926 & 1,46 & $-0,44$ \\
\hline
\end{tabular}

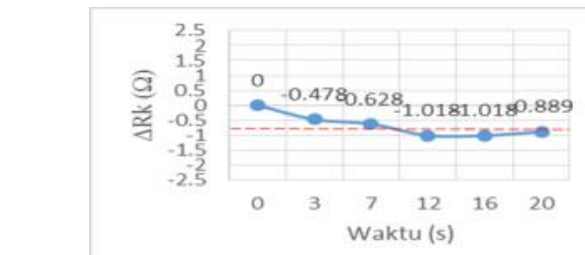

Gambar 13. Grafik Perbandingan Waktu Terhadap Rk Pengujian Ketiga

Tabel 6. Diameter Pupil Mata Pengujian Ketiga

\begin{tabular}{ccc}
\hline Waktu (s) & $\begin{array}{c}\text { Diameter } \\
\text { Pupil (mm) }\end{array}$ & $\mathrm{X}$ \\
\hline 0 & 4,62 & 0 \\
3 & 4,62 & 0 \\
7 & 4,86 & 0,24 \\
12 & 4,74 & 0,12 \\
16 & 4,86 & 0,24 \\
20 & 4,5 & $-0,12$ \\
Jumlah & 28,26 & 0,48 \\
Rata-rata & 4,71 & 0,08 \\
\hline
\end{tabular}

perubahan yang terjadi sebesar $1,1 \mathrm{~mm}$ dari ukuran awal pupil pengujian kedua. Jika dilihat pada Gamabr 12 diatas pada detik ke 12 telah melewati batas yang telah ditentukan. Sehingga pada pengujian detik ke $12 \mathrm{~s}$ pengujian kedua ini berpotensi berbohong.

\section{N. Analisa Alat Pengujian Ketiga}

Pada pengujian ketiga ini setelah dilakukan perhitungan rata-rata nilai tegangan sensor GSR sebesar $0,926 \mathrm{~V}$, resistansi kulit sebesar 1,46 dan perubahan resistansi kulit atau $\mathrm{Rk}$ sebesar 0,44 . Perhitungan pada pengujian ketiga ini dapat dilihat dapat Tabel 5 dibawah ini.

Dari Tabel 5 diatas dapat dibuat grafik perbandingan waktu terhadap perubahan resistansi kulit atau Rk pengujian ketiga pada Gambar 13.

Dari Gambar 13 terlihat untuk nilai perubahan Rk pengujian ketiga terlihat pada detik ke $12 \mathrm{~s}$ dan $16 \mathrm{~s}$ 


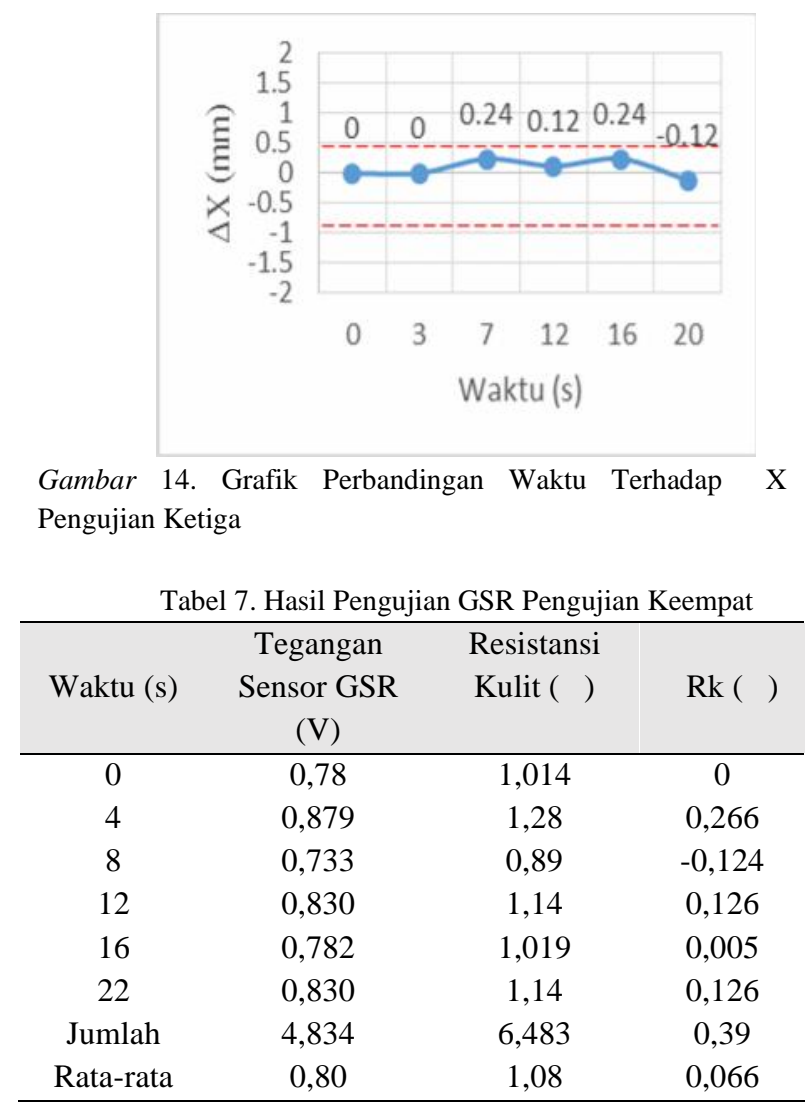

sebesar 1,018 . Nilai tersebut telah melewati batas yang telah ditentukan sehingga pada pengujian ketiga ini berpotensi berbohong.

Setelah dilakukan perhitungan pada GSR selanjutnya dilakukan perhitungan diameter pupil mata yang dapat dilihat pada Tabel 6 .

Dari Tabel 6 terlihat rata-rata ukuran pupil mata untuk pengujian ketiga sebesar 4,71 $\mathrm{mm}$ dan ukuran perubahan pupil mata atau $\mathrm{X}$ sebesar $0,08 \mathrm{~mm}$. Terlihat pada pengujian diameter pupil mata pengujian ketiga ini stabil pada nilai yang telah ditentukan. Dari tabel 6 tersebut dapat dibuat grafik perbandingan waktu terhadap perubahan diameter pupil mata yang ditunjukkan pada Gambar 14.

Dari Gambar 14 terlihat perubahan ukuran pupil mata pada pengujian ketiga stabil dan tidak mengalami perubahan ukuran yang signifikan sehingga pada pengujian ketiga ini berpotensi jujur.

\section{O. Analisa Alat Pengujian Keempat}

Pada pengujian keempat ini setelah dilakukan perhitungan pengujian GSR maka didapat nilai rata-rata tegangan sensor GSR sebesar $0,80 \mathrm{~V}$, resitansi kulit sebesar 1,08 dan perubahan resistansi kulit sebesar 0,066 . Perhitungan pengujian GSR dapat dilihat pada Tabel 7 dibawah ini.

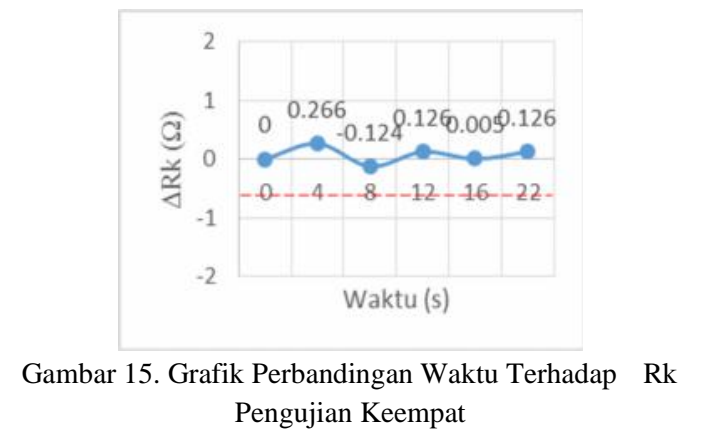

Tabel 8. Diameter Pupil Mata Pengujian Keempat

\begin{tabular}{ccc}
\hline Waktu (s) & $\begin{array}{c}\text { Diameter } \\
\text { Pupil }(\mathrm{mm})\end{array}$ & X (mm) \\
\hline 0 & 7,13 & 0 \\
4 & 7,13 & 0 \\
8 & 6,68 & $-0,45$ \\
12 & 6,50 & $-0,63$ \\
16 & 6,59 & $-0,54$ \\
22 & 6,95 & $-0,18$ \\
Jumlah & 40,98 & $-1,8$ \\
Rata-rata & 6,83 & $-0,3$ \\
\hline
\end{tabular}

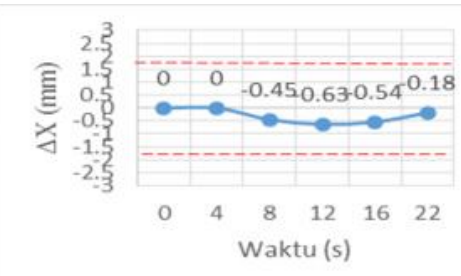

Gambar 15. Grafik Perbandingan Waktu Terhadap X Pengujian Keempat

Dari data Tabel 7 terlihat perubahan resitansi kulit terlihat stabil. Tabel 7 diatas dapat dibuat grafik perbandingan waktu terhadap perubahan nilai resistansi kulit atau Rk untuk pengujian keempat pada Gambar 15.

Dari Gambar 15 terlihat tidak ada nilai perubahan resistansi kulit atau Rk yang melewati batas yang telah ditentukan dn cenderung stabil. Dilihat Gambar 15 maka pengujian keempat ini berpotensi jujur.

Setelah dilakukan perhitungan perubahan resitansi kulit maka dilanjutkan perhitungan perubahan diameter pupil mata. Pada Tabel 8 menunjukkan hasil perhitungan perubahan diameter pupil mata.

Pada Tabel 8 diatas terlihat rata-rata diameter pupil mata pada pengujian keempat sebesar $6,83 \mathrm{~mm}$ dan perubahan ukuran pupil mata atau $\mathrm{X}$ sebesar $0,3 \mathrm{~mm}$. dari hasil diatas terlihat nilainya stabil. Selanjutnya dapat dibuat perbandingan waktu terhadap $\mathrm{X}$ untuk pengujian keempat pada Gambar 15. 


\section{P. Kesimpulan}

Pada perubahan nilai resistansi kulit berpotensi berbohong atau tidak menunjukkan perubahan nilai yang terjadi pada pengujian yang kedua pada detik 12 sebesar 0,244 dan pengujian ketiga pada detik 12 dan 16sebesar 1,018

Pada perubahan ukuran diameter pupil mata berpotensi berbohong atau tidak menunjukkan perubahan nilai terjadi pada pengujian pertama pada detik 11 sebesar $1,31 \mathrm{~mm}$ dan 19 sebesar 0,92 $\mathrm{mm}$ dan juga pada pengujian kedua pada detik 12 sebesar 1,1 $\mathrm{mm}$.

\section{REFERENSI}

[1] A. Harjoko, J. P. Fisika, U. Singaraja, and D. Deception, "Telaah Metode-metode Pendeteksi Kebohongan,” IJCCS (Indonesian J. Comput. Cybern. Syst., vol. 6, no. 2, pp. 35-46, 2013.
[2] F. Syahbarudin, N. C. Basjaruddin, E. Sutjiredjeki, and K. Kunci, "Alat Pengukur Tanda Vital Pada Tubuh dan Tingkat Stres Menggunakan Metode Sensor Fusion," pp. 477-482, 2013.

[3] A. A. Kurniawan, "Rancang Bangun Alat Pendeteksi Kebohongan Menggunakan Sensor Galvanic Skin Response (Gsr) Dan Pulse Heart Sensor Berbasis Arduino Uno," Universitas Stikubank, 2020.

[4] A. J. Lubis, "Perancangan pendeteksian kebohongan melalui perubahan diameter pupil mata dengan teknik," CSRID J., vol. 2, no. 3, pp. 147-156, 2010.

[5] A. Jayanthi, R. Nivedha, and C. Vani, "Galvanic Skin Response Measurement and Analysis," Int. J. Appl. Eng. Res., vol. 10, no. 16, pp. 12447-12452, 2015. 